\title{
Jean-Bernard Vray, François Bon, chiffonier de la mémoire collective dans "Paysage fer»
}

\section{Rosa Galli Pellegrini}

\section{(2) OpenEdition}

1 Journals

\section{Edizione digitale}

URL: https://journals.openedition.org/studifrancesi/41298

DOI: 10.4000/studifrancesi.41298

ISSN: 2421-5856

\section{Editore}

Rosenberg \& Sellier

\section{Edizione cartacea}

Data di pubblicazione: 1 juillet 2004

Paginazione: 225

ISSN: 0039-2944

\section{Notizia bibliografica digitale}

Rosa Galli Pellegrini, «Jean-Bernard Vray, François Bon, chiffonier de la mémoire collective dans «Paysage fer»», Studi Francesi [Online], 142 (XLVIII | I) | 2004, online dal 30 novembre 2015, consultato il 09 septembre 2021. URL: http://journals.openedition.org/studifrancesi/41298 ; DOI: https://doi.org/ 10.4000/studifrancesi.41298

Questo documento è stato generato automaticamente il 9 septembre 2021.

\section{(c) 9 (i) $\Theta$}

Studi Francesi è distribuita con Licenza Creative Commons Attribuzione - Non commerciale - Non opere derivate 4.0 Internazionale. 


\title{
Jean-Bernard Vray, François Bon, chiffonier de la mémoire collective dans «Paysage fer»
}

\author{
Rosa Galli Pellegrini
}

\section{NOTIZIA}

JEAN- BERNARD VRAY, François Bon, chiffonier de la mémoire collective dans «Paysage fer» in La Mémoire des Villes. The Memory of cities, éd. Yves Clavaron et Bernard Dieterle, Publ. de L'Univ. de Saint-Etienne, 2003, pp. 107-122.

1 Lo studio di Vray è centrato su Paysage fer di François Bon, apparso nel 2000, presso l'editore Verdier. Prima di entrare nel merito del romanzo, l'A. pone le premesse dell sua creazione, facendo una panoramica dell'opera di Bon e mettendo in risalto la «maniera seconda» della scrittura dell'autore a partire dalle esperienze degli «ateliers d'écriture» iniziati ne 1992; il suo abbandono del genere rornanzesco per la trascrizione della voce «di coloro che non hanno voce», i derelitti, gli emarginati. La città entra di diritto in questa poetica nuova e Paysage fer ne rappresenta un aspetto forte, attraverso la «vista» di edifici che iscrivono in sé la traccia dell'uomo, e che lo scrittore registra con minuzia e precisione estrema. Appoggiandosi al pensiero di Walter Benjamin, Vray vede nel lavoro di Bon l'intento di ricuperare frammenti di storia sparsi all'interno della città. 